\title{
Combination of CTLA-4 and PD-1 blockers for treatment of cancer
}

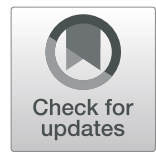

\author{
Anand Rotte
}

\begin{abstract}
Targeting checkpoints of immune cell activation has been demonstrated to be the most effective approach for activation of anti-tumor immune responses. Cytotoxic T-lymphocyte-associated protein 4 (CTLA-4) and programmed cell death protein 1 (PD-1), both inhibitory checkpoints commonly seen on activated T-cells have been found to be the most reliable targets for the treatment of cancer. Six drugs targeting PD-1 or its ligand PD-L1 and one drug targeting CTLA-4 have been approved for treatment of different types of cancers and several others are in advanced stages of development. The drugs when administered as monotherapy had dramatic increase in durable response rates and had manageable safety profile, but more than $50 \%$ of patients failed to respond to treatment. Combination of CTLA-4 and PD-1 blockers was then evaluated to increase the response rates in patients, and ipilimumab (anti-CTLA-4) plus nivolumab (anti-PD-1) combination was shown to significantly enhance efficacy in metastatic melanoma patients. Subsequently, ipilimumab plus nivolumab was approved for treatment of metastatic melanoma, advanced renal cell carcinoma and metastatic colorectal cancer with MMR/MSI-H aberrations. The success of combination encouraged multiple clinical studies in other cancer types. Efficacy of the combination has been shown in a number of published studies and is under evaluation in multiple ongoing studies. This review aims to support future research in combination immunotherapy by discussing the basic details of CTLA-4 and PD-1 pathways and the results from clinical studies that evaluated combination of CTLA-4 and PD-1/PD-L1 blockers.
\end{abstract}

Keywords: Immunotherapy, CTLA-4, PD-1, Combination therapy

\section{Background}

For several decades treatment of advanced cancer has been challenged by lack of reliable therapeutic options. Patients with metastatic tumors that were not surgically resectable had to depend on chemotherapy, which is commonly associated with severe adverse events as well as high rates of relapse. As the understanding of immune system and immune surveillance grew, the idea of utilizing immune cells to eliminate cancer gained significance and various strategies to activate immune response were developed. Administration of interleukin-2 (IL-2), a cytokine known for stimulating T-cell proliferation, is one of the earliest approach tested for cancer treatment and IL-2 is one of the oldest immune based drug approved for the treatment of cancer [1-3]. However, the first generation of immunotherapies were limited by low response rates and high incidence of serious

Correspondence: anand.rotte@gmail.com; anand.rotte@nevro.com Clinical \& Regulatory Affairs, Nevro Corp, 1800 Bridge Parkway, Redwood City, CA 94065, USA

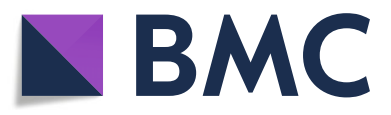

adverse events [4]. The search for dependable targets for the modulation of immune responses led to the discovery of checkpoints of T-cell activation and development of monoclonal antibodies targeting the checkpoints [5-11]. Among the checkpoints, cytotoxic T-lymphocyteassociated protein 4 (CTLA-4) and programmed cell death protein 1 (PD-1) have been found to be the most reliable targets and drugs targeting CTLA-4 and PD-1 drastically changed the outcomes of treatment for advanced cancers. To date, 7 drugs targeting CTLA-4/PD-1 are approved for treatment of different types of cancers including melanoma, lung cancer, breast cancer, head and neck cancer, bladder cancer, Merkel cell cancer, cervical cancer, hepatocellular cancer, gastric cancer, cutaneous squamous cell cancer, classic Hodgkin's lymphoma and B-cell lymphoma (Table 1). The impact of CTLA-4 and PD-1 blockers on cancer research and their success in cancer treatment is acknowledged by researchers as well as clinicians worldwide and rightfully the Nobel Prize in Physiology or Medicine for 2018 was awarded to Professor James Allison,

(C) The Author(s). 2019 Open Access This article is distributed under the terms of the Creative Commons Attribution 4.0 International License (http://creativecommons.org/licenses/by/4.0/), which permits unrestricted use, distribution, and reproduction in any medium, provided you give appropriate credit to the original author(s) and the source, provide a link to the Creative Commons license, and indicate if changes were made. The Creative Commons Public Domain Dedication waiver (http://creativecommons.org/publicdomain/zero/1.0/) applies to the data made available in this article, unless otherwise stated. 
Table 1 List of approved drugs targeting CTLA-4 and PD-1 (current as May 2019)

\begin{tabular}{|c|c|c|}
\hline Drug & Brand name & Indication \\
\hline \multicolumn{3}{|l|}{ CTLA-4 blockers } \\
\hline Ipilimumab & Yervoy & $\begin{array}{l}\text { As monotherapy for metastatic melanoma and surgically resectable 'high-risk' } \\
\text { melanoma (adjuvant setting) }\end{array}$ \\
\hline \multicolumn{3}{|l|}{ PD-1 blockers } \\
\hline Nivolumab & Opdivo & $\begin{array}{l}\text { Metastatic melanoma, metastatic non-small-cell lung cancer (NSCLC), renal cell } \\
\text { carcinoma (RCC), classical Hodgkin's lymphoma, head and neck squamous cell } \\
\text { carcinoma (HNSCC), metastatic urothelial carcinoma, hepatocellular carcinoma } \\
\text { (HCC), colorectal cancer with MSI-H and MMR aberrations }\end{array}$ \\
\hline Pembrolizumab & Keytruda & $\begin{array}{l}\text { Metastatic melanoma, surgically resectable 'high-risk melanoma (adjuvant } \\
\text { setting), metastatic NSCLC, classical Hodgkin's lymphoma, primary mediastinal } \\
\text { B-cell lymphoma (PMBCL), HNSCC, gastric cancer, solid tumors with MSI-H and } \\
\text { MMR aberrations, metastatic urothelial carcinoma, Merkel cell carcinoma, renal } \\
\text { cell carcinoma, cervical cancer, hepatocellular carcinoma, }\end{array}$ \\
\hline Cemiplimab & Libtayo & $\begin{array}{l}\text { Metastatic cutaneous squamous cell carcinoma (CSCC) or locally advanced CSCC } \\
\text { who are not candidates for curative surgery or curative radiation }\end{array}$ \\
\hline \multicolumn{3}{|l|}{ PD-L1 blockers } \\
\hline Atezolizumab & Tecentriq & $\begin{array}{l}\text { Metastatic urothelial carcinoma, metastatic NSCLC (monotherapy and in } \\
\text { combination with chemotherapy), metastatic SCLC (in combination with } \\
\text { chemotherapy) and metastatic triple negative breast cancer (in combination } \\
\text { with paclitaxel) }\end{array}$ \\
\hline Avelumab & Bevencio & Merkel cell carcinoma, metastatic urothelial carcinoma \\
\hline Durvalumab & Imfinzi & Metastatic urothelial carcinoma, unresectable stage III NSCLC \\
\hline \multicolumn{3}{|c|}{ Combination of CTLA-4 and PD-1 blockers } \\
\hline Ipilimumab plus nivolumab & Yervoy plus Opdivo & $\begin{array}{l}\text { Metastatic melanoma, metastatic renal cell carcinoma, colorectal cancer with } \\
\text { MSI-H and MMR aberrations }\end{array}$ \\
\hline
\end{tabular}

MD Anderson Cancer Center, USA and Professor Tasuku Honjo, Kyoto University, Japan for their research on CTLA-4 and PD-1 respectively [12].

Main advantages of CTLA-4 and PD-1 blockers are impressive durable response rates and manageable adverse events, but only a fraction of patients were seen to respond to monotherapy [13-15]. Combination of CTLA-4 and PD-1 blockers was suggested to have synergistic effect on activation of anti-tumor immune response and to increase the response rates in patients. Multiple clinical studies were conducted to test the safety and efficacy of the combination in different cancer subtypes. The combination showed remarkable increase in response rates and median survival times in melanoma and renal cell carcinoma, resulting in approval of the ipilimumab and nivolumab combination for their treatment. Additional studies in difficult to treat cancer types such as non-small cell lung cancer, mesothelioma, sarcoma and esophagogastric cancers have shown improved response rates in patients treated with combination therapy. The present review aims to discuss the results from clinical studies that evaluated combination of CTLA-4 and PD- 1 blockers to support future research in combination immunotherapy. Basic details of CTLA-4 and PD-1 including their expression, ligands and role in immune response are described in the following sections to help in easier understanding of mechanisms of action.

\section{CTLA-4}

CTLA-4 (cluster of differentiation 152, CD152), is a receptor found on surface of activated T-cells. It was discovered through screening of mouse cytolytic T-cell derived cDNA libraries by Brunet et al in 1987 [16]. The location of human CTLA-4 gene and the details of the protein encoded by CTLA-4 gene are listed in Table 2 . CTLA-4 expression is normally seen upon activation of T-cells, but regulatory T-cells (Tregs), express CTLA-4 constitutively due to their high levels of forkhead transcription factor FoxP3, which is known to regulate CTLA-4 expression [17-19]. CTLA-4 mainly acts by competing with $\mathrm{CD} 28$ receptors for binding to $\mathrm{B} 7 \mathrm{li}$ gands (B7-1/CD80 and B7-2/CD86) on antigen presenting cells (APCs). During T-cell activation, CD28 receptors on T-cells bind to $\mathrm{B} 7$ ligands on $\mathrm{APCs}$ and provide the essential second activation signal for T-cells. However, CTLA-4 receptors bind to B7 ligands with higher affinity and at a lower surface density and thereby outcompete CD28 receptors for binding with B7 ligands. Lack of second activation signal in presence of CTLA-4 receptors would thus lead to anergy in T-cells [20-22]. In addition, CTLA-4 receptors are also shown to sequester B7-ligands from the surface of the APCs and result in significant depletion of the ligands on their surface.

Intriguingly, due to its structural similarity with CD28 and its expression on activated T-cells, CTLA-4 was 
Table 2 Summary of CTLA-4 and PD1

\begin{tabular}{|c|c|c|}
\hline Receptor & CTLA-4 & PD-1 \\
\hline Synonyms & CD152 & PDCD1, CD279 \\
\hline Gene location & Chromosome 2q33 & Chromosome 2q37.3 \\
\hline Protein details & $\begin{array}{l}\text { Amino acids \#223 } \\
\text { Type } 1 \text { transmembrane glycoprotein belonging to } \\
\text { Ig super family } \\
\text { Dimer } \\
\text { Domains: a single peptide, an extracellular ligand- } \\
\text { binding domain, a transmembrane domain, and a } \\
\text { short cytoplasmic tail }\end{array}$ & $\begin{array}{l}\text { Amino acids \#288 } \\
\text { Type I transmembrane protein belonging to Ig super } \\
\text { family } \\
\text { Monomer } \\
\text { Domains: extracellular N-terminal IgV-like domain, a } \\
\text { transmembrane domain, and a cytoplasmic tail }\end{array}$ \\
\hline Signaling motif & Cytoplasmic tail & ITSM \\
\hline Cells expressing receptor & Effector T-cells \& TRegs & Effector T-cells, TRegs, NK cells \& macrophages \\
\hline Ligands & CD80 (B7-1), CD86 (B7-2) & PD-L1 (B7-H1), PD-L2 (B7-DC) \\
\hline Cells expressing ligands & APCs & $\begin{array}{l}\text { APCs, hematopoetic \& nonhematopoetic cells \& } \\
\text { tumor cells }\end{array}$ \\
\hline
\end{tabular}

thought to be a positive regulator of T-cells in the initial days of its discovery. Professor Allison is credited for demonstrating the negative role of CTLA-4 and establishing the opposing effects of CTLA-4 and CD28 in response to T-cell stimulation. His research clearly showed that CTLA-4 engagement with B7-ligands abrogated IL2 secretion by $\mathrm{T}$-cells and $\mathrm{T}$-cell proliferation that followed TCR activation; that blockade of CTLA-4 using anti-CTLA-4 antibodies resulted in rejection of preestablished tumors and that the mice lacking Ctla4 gene $\left(\mathrm{Ctla}^{-/-}\right.$mice) develop severe lymphoproliferative and lethal autoimmune phenotype [23-25].

Further studies showed that CTLA-4 engagement activated intrinsic signaling cascades in T-cells. CTLA-4 activation was reported to inhibit IL-2 production and T cell proliferation and induce cell cycle arrest through cross-talks with pathways regulating cell survival and proliferation, including PI3K, NFkB and MAPK pathways [26-30]. Based on the potential of CTLA-4 blockade for treatment of cancer seen in murine tumor models, anti-CTLA-4 antibodies were developed [24]. Among them, ipilimumab was approved for unresectable metastatic melanoma as well as adjuvant to surgery for 'high-risk' melanoma [31-38].

\section{PD-1}

PD-1 (PDCD1 and CD279) is a cell surface receptor commonly seen on T cells, B cells and NK cells. Professor Honjo and coworkers are credited for the discovery of PD-1 through their studies on pathways of programmed cell death [39]. The details of human PD-1 gene location and the encoded protein are listed in Table 2. There is some similarity (21-33\%) between extracellular domain of PD-1 and CTLA-4, but unlike CTLA-4, a dimeric protein, PD-1 lacks the extracellular cysteine residue required for covalent dimerization and exists as a monomer on cell surface and also in solution [40].
Basal level of PD-1 is seen on B cells but not on naïve T cells; its expression is induced upon activation of TCR/ BCR. Apart from T cells, NK cells and B cells, PD-1 is also expressed on Tregs, NKT cells, activated monocytes and myeloid DCs. The ligands for PD-1, PD-L1 (B7-H1) and PD-L2 (B7-DC) are commonly expressed on macrophages and DCs [41, 42]. PD-L1 is also expressed on T-cells, B-cells, vascular endothelial cells, fibroblastic reticular cells, epithelial cells, pancreatic islet cells, astrocytes, neurons as well as on sites of immune privilege such as trophoblasts in placenta and retinal pigment epithelial cells [42-44]. Upon binding with their ligands, PD-1 receptors inhibit cell proliferation, cytokine secretion and cytotoxic ability of effector immune cells and thereby blunt the immune response [45]. Recently, using knock-in mice researchers from Tokushima University, Japan, showed that the function of PD-1 receptors was restricted during early stages of T-cell activation by cis interaction of CD80 and PD-L1 on APCs thereby preventing PD-L1/PD-1 binding [46].

PD-1 receptors are known to activate downstream signaling pathways and promote the differentiation of induced Treg (iTreg) cells in murine models through induction of FoxP3 expression [41]. Activation of PD-1 receptors was shown to result in phosphorylation of the tyrosine residue located within ITSM motifs of the cytoplasmic tails, recruitment of phosphatases SHP1 and SHP2 and dephosphorylation of downstream effectors such as Syk, PI3K, ZAP70 and CD3C. Through inhibition of PI3K pathway, PD-1 signaling was shown to prevent activation of the cell survival factor Bcl-xL and abrogate the expression of transcription factors that regulate the effector functions of T-cells such as GATA-3, T-bet and Eomes [44]. Interestingly, activation of TCR via CD28 or activation of downstream mediators of PI3K/Akt pathway such as STAT5 by cytokines including IL-2, IL-7 and IL-15 was shown to blunt the extent of PD-1 mediated inhibition $[47,48]$. 
Early studies in knock out mice demonstrated the importance of PD-1 in regulation of immune response. While the phenotype was comparatively mild, mice lacking PD-1 developed autoimmune disorders such as lupus like syndrome, characterized by glomerulonephritis and arthritis and autoimmune dilated cardiomyopathy $[49,50]$. PD-1/PD-L1 pathway is found to play a key role in escape of cancer from immunosurveillance, with PD-1 expression seen on effector T-cells and exhausted T-cells in tumor microenvironment (TME) and PD-L1 expression seen on cell surface in several types of cancers including bladder, lung, colon, breast, kidney, ovary, cervix, melanoma, glioblastoma, multiple myeloma and T-cell lymphoma [41, 43]. Blockade of PD-1/ PD-L1 pathway to stimulate anti-tumor immune responses has been the most successful strategy to date. Three monoclonal anti PD-1antibodies, pembrolizumab, nivolumab and cemiplimab and 3 monoclonal anti-PD-L1 antibodies, atezolizumab, avelumab and durvalumab are approved by US FDA for the treatment of different types of cancer [9, 51-81].

\section{Rationale for combination}

When administered as monotherapy in clinical studies, CTLA-4 and PD-1 blockers demonstrated impressive durable response rates, increased the survival time of responding patients significantly and had a manageable safety profile $[4,13-15]$. However, benefits of monotherapy were limited by low response rates and only a fraction of patients were found to respond to the therapy [13]. For example, more than $50 \%$ of metastatic melanoma patients failed to respond to monotherapy as seen by objective response rates (ORR) for ipilimumab (10$16 \%)$ and for nivolumab and pembrolizumab (30-40\%) [36, 37, 51, 52, 68, 69]. Combination of CTLA-4 and PD-1 blockade was thus proposed to increase the response rates and survival rates of the patients. It was thought that blockade of CTLA-4, which is primarily involved in regulation of T-cell activation in lymph nodes/ tissues and in suppression of DC activity via Treg cells, would act synergistically with blockade of PD-1 that is mainly involved in inhibition of effector T-cell and NK cell activation in peripheral tissues and in induction of Treg cell differentiation (Fig. 1) [25, 49, 50, 82, 83]. Results from clinical trials that evaluated the efficacy of CTLA-4 plus PD-1 blockers and demonstrated the benefits of combination therapy are discussed in the following section.

\section{Clinical evidence}

\section{Melanoma}

Anti-CTLA-4 (ipilimumab) and anti-PD-1 (nivolumab and pembrolizumab) combination was studied extensively in metastatic melanoma patients and the efficacy of the combination was demonstrated in multiple clinical trials [84-94]. In a phase 1 study, ipilimumab plus nivolumab combination was reported to increase the ORR to $61 \%(n=44 / 72)$, with complete responses seen in $22 \%(n=16 / 72)$ patients. Patients assigned to combination therapy in the study reportedly had significantly lower incidence of disease progression or death; hazard ratio (HR) for disease progression or death in combination therapy group versus ipilimumab monotherapy was $0.40(p<0.001)$ [85]. In another phase 2 study, patients treated with combination therapy increased the 2year overall survival (OS) rate to $63.8 \%$ at the time of median follow-up time [92]. In the phase 3 study, patients treated with nivolumab plus ipilimumab had higher ORR (57\%, 19\% and 44\% respectively), longer median progression free survival (PFS, 11.5, 2.9 and 6.9 months respectively) and lower incidence of disease progression or death (HR, 0.42 and 0.57 respectively, $p<$ 0.001 for both) compared to ipilimumab and nivolumab monotherapy [86]. Results from analyses of outcomes after 3-year and 4-year follow-up of the patients in the study further showed the superior benefits of combination therapy over monotherapy [87, 88]. Combination therapy showed sustained OS rate of over $50 \%$ at both 3-year and 4-year assessment (Table 3). Pooled analysis of data from patients treated with nivolumab alone or in combination with ipilimumab in clinical studies including phase 3 trials, further showed that patients receiving combination therapy had higher median PFS, 11.7 months for cutaneous melanoma patients and 5.9 months for mucosal melanoma patients compared to nivolumab monotherapy group (6.2 months and 3.0 months respectively) [95]. To address the increased incidence of adverse events seen with combination therapy, alterations in the sequence of administration of nivolumab and ipilimumab was tested in a phase 2 study, in which, patients either received nivolumab for six doses followed by a planned switch to ipilimumab for four doses or ipilimumab for four doses followed by nivolumab for six doses. Interestingly, disease progression was lower and overall survival was better when nivolumab was administered first followed by ipilimumab, but there was no significant difference in frequencies of treatment related grade 3-5 adverse events between the two groups [91].

\section{Pembrolizumab plus ipilimumab combination}

In a phase $1 \mathrm{~b}$ study, efficacy of regular dose pembrolizumab plus low dose ipilimumab combination was studied in metastatic melanoma patients. Interestingly, pembrolizumab and low-dose ipilimumab combination also showed comparable efficacy with ORR of 61\%, 1-year PFS rate of $69 \%$ and 1-year OS rate of $89 \%$ but had lower incidence of grade 3-4 adverse events (46\%) [89]. Results from 


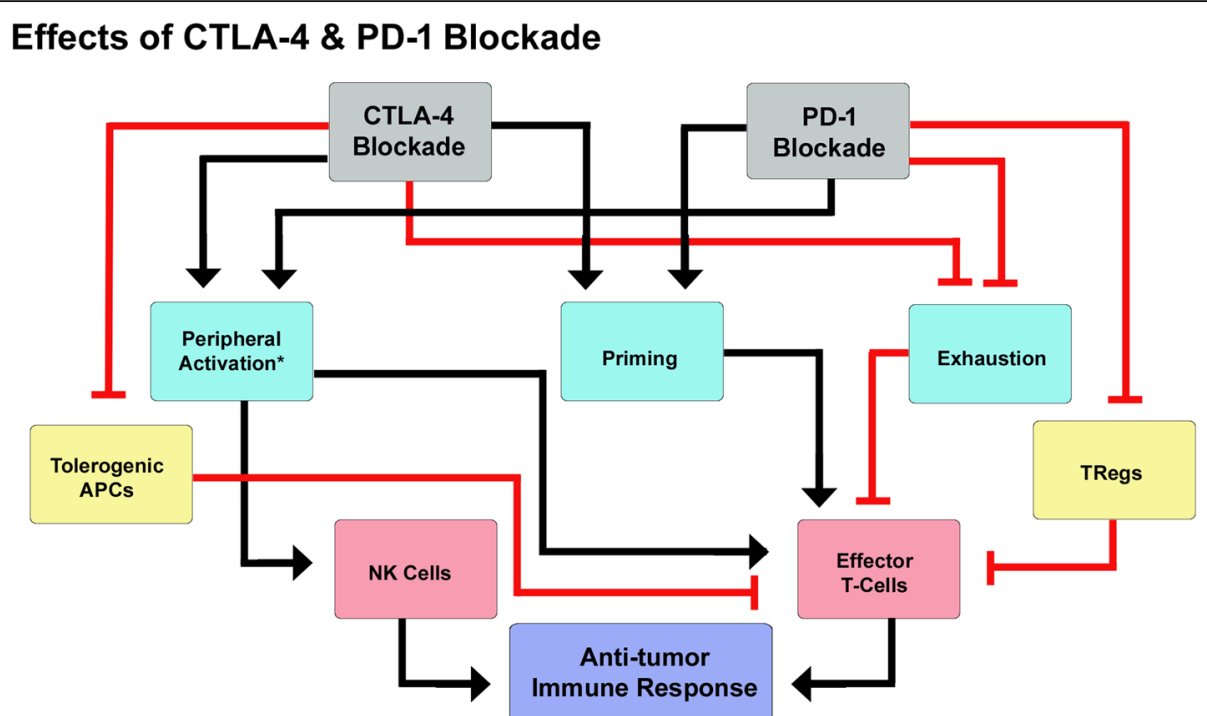

Fig. 1 Effects of combined blockade of CTLA-4 and PD-1. *-NK cells do not express CTLA-4 and are not expected to be activated by CTLA-4 blockade

analysis of 'real-world' outcomes showed that metastatic cutaneous melanoma patients treated with the combination of pembrolizumab and low-dose ipilimumab had an overall response rate of $38 \%$ and lower incidence of grade 3-4 adverse events (18\%) [96].

\section{Nivolumab plus ipilimumab for surgically resectable 'high- risk' melanoma}

Anti-CTLA-4 and anti-PD-1 combination was also tested for the treatment of melanoma in adjuvant and neoadjuvant settings. In a feasibility study, patients with palpable stage III melanoma received either four doses of ipilimumab and nivolumab combination after surgery (adjuvant setting) or two doses of the combination before surgery and two doses after surgery (neoadjuvant setting). The study reported that neoadjuvant administration of ipilimumab and nivolumab combination induced pathological responses in $78 \%(N=7 / 9)$ patients and had comparatively higher expansion of tumor resident T-cell clones. At the time of reporting (median follow-up, 25.6 months), none of the patients had relapse of the disease. Authors concluded that while the neoadjuvant therapy was promising, further research was needed to reduce toxicity while preserving efficacy [97].

\section{Renal cell carcinoma}

Combination of anti-CTLA-4 (ipilimumab) and anti-PD1 (nivolumab) antibodies for the treatment of metastatic renal cell carcinoma was first tested in a phase 1 study and was followed up in a phase 3 study (Table 3) [98, 99]. Phase 1 study was designed to test multiple dose regimens of the combination. Results showed that while the ORR (40.4\% for both arms) and 2-year OS rate (67.3\% and
69.6\% respectively) was not different between patients who received nivolumab $3 \mathrm{mg} / \mathrm{kg}$ plus ipilimumab $1 \mathrm{mg} / \mathrm{kg}$ (N3/I1 group) and nivolumab $1 \mathrm{mg} / \mathrm{kg}$ plus ipilimumab 3 $\mathrm{mg} / \mathrm{kg}$ (N1/I3 group), treatment-related grade 3-4 adverse events were comparatively higher in N1/I3 group (38.3\% and $61.7 \%$ respectively) [98]. In the randomized phase 3 trial that followed, nivolumab $3 \mathrm{mg} / \mathrm{kg}$ plus ipilimumab 1 $\mathrm{mg} / \mathrm{kg}$ was chosen for the treatment. The study reported 18 -month OS rate of $75 \%$, ORR of $42 \%$ (complete response rate, 9\%) and median PFS of 11.6 months in the combination group. The incidence of death and disease progression or death in the combination group was lower compared to control (sunitinib) group (HR for death, 0.63, $p<0.001$, significant; HR for disease progression or death, $0.82, p=0.03$, not significant per the prespecified 0.009 threshold) [99]. In a follow-up analysis, patient reported outcomes from the phase 3 trial were studied, which showed that patients in nivolumab plus ipilimumab group had fewer symptoms and had better health related quality of life compared to the control group [100].

\section{Colorectal cancer}

Colorectal cancer with DNA mismatch repair-deficient (dMMR) or microsatellite instability high (MSI-H) positive tumors was expected to respond to immunotherapy due to high levels of tumor neoantigens, tumorinfiltrating lymphocytes and expression of immune checkpoints. In an open-label phase 2 study, blockade of PD-1 receptors with nivolumab recorded an ORR of $31 \%$, disease control rate of $69 \%$ and 12 -month OS rate of $73 \%$ [101]. In the follow-up report, investigators from the study showed that combination of nivolumab and ipilimumab had an investigator-assessed ORR of 55\% and disease control rate of $80 \%$. PFS rates at 9-month 
Table 3 Clinical studies that supported approval of the combination

\begin{tabular}{|c|c|c|c|c|}
\hline Patients & Trial, ID & Follow-up & Outcomes & Reference \\
\hline Advanced melanoma & $\begin{array}{l}\text { Phase } 1 \\
\text { NCT01024231 }\end{array}$ & $\geq 24$ weeks & $\begin{array}{l}\text { ORR, 53\% } \\
\text { Grade 3-4 AEs, 53\% }\end{array}$ & Wolchok et al 2013 \\
\hline Previously untreated advanced melanoma & $\begin{array}{l}\text { Phase } 1 \\
\text { NCT01927419 }\end{array}$ & $\geq 11$ months & $\begin{array}{l}\text { In patients with BRAF-WT tumors } \\
\text { ORR } 61 \% \\
\text { Median PFS, not reached } \\
\text { HR for disease progression or death, } 0.40 \\
\text { Grade } 3-4 \text { AEs, } 54 \%\end{array}$ & Postow et al 2015 \\
\hline Previously untreated advanced melanoma & $\begin{array}{l}\text { Phase } 3 \\
\text { NCT01844505 }\end{array}$ & $>12$ months & $\begin{array}{l}\text { Median PFS, } 11.5 \text { months } \\
\text { HR for death or disease progression, } 0.42 \\
\text { Investigator assessed ORR, } 57 \% \\
\text { Grade 3-4 AEs, 55\% }\end{array}$ & Larkin et al 2015 \\
\hline Previously untreated advanced melanoma & $\begin{array}{l}\text { Phase } 3 \\
\text { NCT01844505 }\end{array}$ & $\geq 36$ months & $\begin{array}{l}\text { Median OS, not reached } \\
3 \text {-year OS rate, } 58 \% \\
\text { HR for death, } 0.55 \\
\text { Grade } 3-4 \text { AEs, } 59 \%\end{array}$ & Wolchok et al 2017 \\
\hline Previously untreated advanced melanoma & $\begin{array}{l}\text { Phase } 3 \\
\text { NCT01844505 }\end{array}$ & $\geq 48$ months & $\begin{array}{l}\text { Median OS, not reached } \\
\text { 4-year OS rate, } 54 \% \\
\text { ORR, } 58 \% \\
\text { HR for death, } 0.54 \\
\text { HR for progression-free survival, } 0.42 \\
\text { Grade 3-4 AEs, } 59 \%\end{array}$ & Hodi et al 2018 \\
\hline $\begin{array}{l}\text { Advanced melanoma patients with at } \\
\text { least one brain metastasis }\end{array}$ & $\begin{array}{l}\text { Phase } 2 \\
\text { NCT02320058 }\end{array}$ & $\geq 6$ months & $\begin{array}{l}\text { Rate of intracranial clinical benefit, } 57 \% \text {; } \\
\text { Rate of extracranial clinical benefit, 56\% } \\
\text { 9-month PFS (global) rate, 57\%; 9-month } \\
\text { OS rate, } 83 \\
\text { 12-month OS rate, } 82 \% \\
\text { Grade 3-4 AEs, } 55 \%\end{array}$ & Tawbi et al 2018 \\
\hline Advanced melanoma & $\begin{array}{l}\text { Phase } 2 \\
\text { NCT01783938 }\end{array}$ & $\geq 15$ months & $\begin{array}{l}\text { ORR, } 56 \% \\
\text { Median OS, not reached } \\
\text { 1-year OS rate, } 76 \% \\
\text { Grade 3-5 AEs, } 50 \%\end{array}$ & Weber et al 2018 \\
\hline $\begin{array}{l}\text { Previously untreated advanced clear } \\
\text { cell renal cell carcinoma }\end{array}$ & $\begin{array}{l}\text { Phase } 3 \\
\text { NCT02231749 }\end{array}$ & $>17$ months & $\begin{array}{l}\text { ORR, } 42 \% \\
\text { Median OS, not reached } \\
\text { HR for death, } 0.63 \\
\text { Median PFS, } 11.6 \text { months } \\
\text { HR for disease progression, } 0.82\end{array}$ & Motzer et al 2018 \\
\hline $\begin{array}{l}\text { Previously treated, MMR/MSI-H positive } \\
\text { advanced colorectal cancer }\end{array}$ & $\begin{array}{l}\text { Phase } 2 \\
\text { NCT02060188 }\end{array}$ & $>9$ months & $\begin{array}{l}\text { ORR, } 55 \% \\
\text { Median PFS, not reached } \\
12 \text {-month PFS rate, } 71 \% \\
\text { Median OS, not reached } \\
12 \text {-month OS rate, } 85 \% \\
\text { Grade 3-4 AEs, 32\% }\end{array}$ & Overman et al 2018 \\
\hline
\end{tabular}

and 12 -month were $76 \%$ and $71 \%$ respectively and OS rates were $87 \%$ and $85 \%$ respectively. Authors concluded that combination of nivolumab and ipilimumab had comparatively better efficacy and was a promising new treatment option for metastatic colorectal cancer patients with $\mathrm{dMMR} / \mathrm{MSI}-\mathrm{H}$ positive tumors [102].

\section{Lung cancer \\ Durvalumab plus tremelimumab for non-small cell lung cancer (NSCLC)}

Multiple studies investigated the efficacy of anti-PD-1/ PD-L1 plus anti-CTLA-4 antibodies in lung cancer (Table 4). The first study (phase 1b) evaluated the safety and efficacy of durvalumab (anti-PD-L1) and tremelimumab (anti-CTLA-4) combination in patients with advanced squamous or non-squamous NSCLC across five cancer centers in USA. The study reported clinical activity in patients with PD-L1 positive tumors as well as PD-L1 negative tumors with investigator assessed confirmed ORR in $23 \%$ patients [103].

\section{Nivolumab plus ipilimumab for NSCLC}

Safety and activity of nivolumab and ipilimumab combination as first-line therapy for NSCLC was tested in a phase 1 study. Two different dosage regimens of the combination including, nivolumab every 2 weeks plus ipilimumab every 12 weeks and nivolumab every 2 weeks plus ipilimumab every 6 weeks were evaluated in the study. At the time of reporting, confirmed ORR appeared to be slightly higher ( $47 \%$ versus $38 \%$ respectively) in patients receiving 
Table 4 Clinical studies in Lung Cancer

\begin{tabular}{|c|c|c|c|c|}
\hline Patients & Trial, ID & Follow-up & Outcomes & Reference \\
\hline Advanced NSCLC & $\begin{array}{l}\text { Phase } 1 \mathrm{~b} \\
\text { NCT02000947 }\end{array}$ & 24 weeks & $\begin{array}{l}\text { ORR, 23\% } \\
\text { Grade 3-4 AEs, 35\% }\end{array}$ & Antonia et al 2016 \\
\hline Treatment relapsed advanced SCLC & $\begin{array}{l}\text { Phase } 1 / 2 \\
\text { NCT01928394 }\end{array}$ & $\geq 12$ weeks & $\begin{array}{l}\text { ORR, } 23 \% \\
\text { Median OS, } 7.7 \text { months } \\
\text { 1-year OS rate, } 43 \% \\
\text { Median PFS, } 2.6 \text { months } \\
\text { 1-year PFS rate, } 19 \% \\
\text { Grade } 3-4 \text { AEs, } 30 \%\end{array}$ & Antonia et al 2016 \\
\hline Untreated advanced NSCLC & Phase 1 NCT01454102 & $>9$ months & $\begin{array}{l}\text { ORR, } 47 \% \\
\text { Median PFS, } 8.1 \text { months } \\
\text { 24-week PFS rate, 68\% } \\
\text { Grade 3-4 AEs, 37\% }\end{array}$ & Hellman et al 2017 \\
\hline Untreated advanced NSCLC & $\begin{array}{l}\text { Phase } 2 \\
\text { NCT02659059 }\end{array}$ & $\geq 6$ months & $\begin{array}{l}\text { In patients with } T M B \geq 10 \text { mutations/megabase } \\
\text { ORR, } 44 \% \\
\text { Median PFS, } 7.1 \text { months } \\
\text { 6-month PFS rate, } 55 \% \\
\text { Grade 3-4 AEs, } 29 \% \text { (all patients) }\end{array}$ & Ready et al 2019 \\
\hline Untreated advanced NSCLC & $\begin{array}{l}\text { Phase } 3 \\
\text { NCT02477826 }\end{array}$ & $>11$ months & $\begin{array}{l}\text { In patients with } T M B \geq 10 \text { mutations/megabase } \\
\text { ORR, } 45 \% \\
\text { Median PFS, } 7.2 \text { months } \\
\text { 12-month PFS rate, } 43 \% \\
\text { HR for disease progression or death, } 0.58 \\
\text { Grade } 3-4 \text { AEs, } 31 \%\end{array}$ & Hellman et al 2018 \\
\hline
\end{tabular}

ipilimumab every 12 weeks compared to patients receiving ipilimumab every 6 weeks [104]. An open-label phase 3 trial was then initiated in patients with stage IV or recurrent NSCLC that was not previously treated with chemotherapy. The study showed that in patients with high tumor mutational burden ( $\geq 10$ mutations per megabase) nivolumab plus ipilimumab combination achieved ORR of $45.3 \%$, 1-year progression free survival rate of $42.6 \%$ and median PFS of 7.2 months. The relative incidence of disease progression or death was significantly lower in nivolumab plus ipilimumab combination group compared to chemotherapy group (HR for disease progression or death, $0.58, p<0.001)$. In patients with tumor mutational burden of at least 10 mutations per megabase and PD-L1 expression of at least 1\%, nivolumab monotherapy group in the study had lower median PFS (4.1 months) compared to nivolumab plus ipilimumab combination (7.1 months); HR for disease progression or death between combination group and monotherapy group was 0.75 [105]. In the following open-label phase 2 study, the efficacy and safety of nivolumab plus 'low-dose' ipilimumab as first-line treatment for metastatic NSCLC was tested and the association of efficacy with PD-L1 expression and tumor mutational burden was assessed. Study showed that ORR was higher in patients with tumor mutational burden of at least 10 mutations per megabase and was not dependent on PD-L1 expression ( $48 \%$ in $\mathrm{PD}-\mathrm{L} 1 \geq 1 \%$ group and $47 \%$ in $\mathrm{PD}-\mathrm{L} 1 \leq 1 \%$ group), and proposed $\geq 10$ mutations per megabase as the cutoff for tumor mutational burden [106].
Nivolumab plus ipilimumab for small cell lung cancer (SCLC) In addition to NSCLC, combination of nivolumab and ipilimumab was tested in patients with advanced SCLC. In a multicenter phase $1 / 2$ study, patients who relapsed after at least one previous platinum-containing regimen were treated with nivolumab plus ipilimumab or nivolumab alone. At the time of assessment, patients receiving combination of nivolumab and ipilimumab had higher ORR (23\% versus 10\%) and longer survival (median OS, 7.7 versus 4.4 months and 1-year OS rate, $43 \%$ versus $33 \%)$ compared to nivolumab monotherapy, further confirming the benefits of combining PD-1 and CTLA-4 blockers [107].

\section{Mesothelioma}

Combination of anti-PD-1 and anti-CTLA-4 antibodies was tested in two phase 2 trials in patients with malignant pleural mesothelioma (Table 5). In the first study, a prospective single center, single arm trial, malignant pleural mesothelioma patients who progressed after at least one line of platinum-containing chemotherapy, were treated with nivolumab plus ipilimumab combination. The study noted that in the eligible patients with evaluable response, stable disease was achieved in $38 \%$ patients, partial response in $29 \%$ patients and disease control in $68 \%$ patients [108]. In the second study, a prospective, randomized, non-comparative, open label, multicenter trial, patients progressing after first-line or second-line pemetrexed or platinum-based treatments were treated with nivolumab plus ipilimumab combination or nivolumab alone. The study reported that in the 
Table 5 Clinical studies in other cancer types

\begin{tabular}{|c|c|c|c|c|c|}
\hline Cancer type & Patients & Trial, ID & Follow-up & Outcomes & Reference \\
\hline $\begin{array}{l}\text { Malignant pleural } \\
\text { mesothelioma }\end{array}$ & Previously treated & $\begin{array}{l}\text { Phase } 2 \\
\text { NCT03048474 }\end{array}$ & $>12$ months & $\begin{array}{l}\text { ORR, 38\% } \\
\text { Median PFS, } 6.2 \text { months } \\
\text { 6-month PFS rate, 50\% } \\
\text { Median OS, not reached } \\
\text { 12-month OS rate, 64\% } \\
\text { Grade 3-4 AEs, 38\% }\end{array}$ & Disselhorst et al 2019 \\
\hline $\begin{array}{l}\text { Malignant pleural } \\
\text { mesothelioma }\end{array}$ & Previously treated & $\begin{array}{l}\text { Phase } 2 \\
\text { NCT02716272 }\end{array}$ & $>16$ months & $\begin{array}{l}\text { ORR, } 28 \% \\
\text { Median PFS, } 5.6 \text { months } \\
\text { 12-month PFS rate, } 23 \% \\
\text { Median OS rate, } 15.9 \text { months } \\
\text { 12-month OS rate, } 58 \% \\
\text { Grade } 3 \text {-4 AEs, } 26 \%\end{array}$ & Scherpereel et al 2019 \\
\hline Unresectable Sarcoma & Previously treated & $\begin{array}{l}\text { Phase } 2 \\
\text { NCT02500797 }\end{array}$ & $>12$ months & $\begin{array}{l}\text { Confirmed response, } 16 \% \\
\text { Median PFS, } 4.1 \text { months } \\
\text { Median OS, } 14.3 \text { months } \\
\text { Grade 3-4 AEs, } 14 \%\end{array}$ & D’Angelo et al 2018 \\
\hline Esophagogastric cancer & Previously treated & $\begin{array}{l}\text { Phase } 1 / 2 \\
\text { NCT01928394 }\end{array}$ & & $\begin{array}{l}\text { Investigator assessed ORR, 24\% } \\
\text { Median PFS, } 1.4 \text { months } \\
\text { 12-month PFS rate, 17\% } \\
\text { Median OS, } 6.9 \text { months } \\
\text { 18-month OS rate, 28\% } \\
\text { Grade 3-4 AEs, 35\% }\end{array}$ & Janjigian et al 2018 \\
\hline Prostate cancer & $\begin{array}{l}\text { Previously treated, } \\
\text { AR-V7 positive }\end{array}$ & $\begin{array}{l}\text { Phase } 2 \\
\text { NCT02601014 }\end{array}$ & $\geq 1.9$ months & $\begin{array}{l}\text { ORR, 25\% } \\
\text { Median PFS,3.7 months } \\
\text { Median OS, } 8.2 \text { months } \\
\text { Grade 3-4 AEs, } 46 \%\end{array}$ & Boudadi et al 2018 \\
\hline
\end{tabular}

intention-to-treat population, disease control was achieved in $52 \%$ patients in combination group and $40 \%$ patients in monotherapy group [109]. Authors from both studies concluded that nivolumab and ipilimumab combination showed promising activity in malignant pleural mesothelioma patients who progressed after chemotherapy and recommended confirming the efficacy in larger trials.

\section{Esophagogastric cancer}

Benefits of combined blockade of PD-1 and CTLA-4 was evaluated in a multicenter trial in patients with locally advanced or metastatic esophagogastric cancers (Table 5). Patients who relapsed after prior chemotherapy received either nivolumab monotherapy or nivolumab plus ipilimumab combination in the study. Analysis of the outcomes revealed that investigator-assessed ORR were seen in $24 \%$ patients receiving the combination of nivolumab and ipilimumab and in $12 \%$ receiving nivolumab alone. 12-month PFS rates $17 \%$ and $8 \%$, and 12 month OS rates were $35 \%$ and $39 \%$ respectively. Interestingly, out of the two different dose cohorts included to evaluate the combination, patients receiving nivolu$\mathrm{mab} 1 \mathrm{mg} / \mathrm{kg}$ and ipilimumab $3 \mathrm{mg} / \mathrm{kg}$ had comparatively better objective response rate (24\% versus $8 \%$ respectively), 12 -month PFS rate (17\% versus $10 \%$ respectively) and 12 - month OS rate (35\% versus $24 \%$ ). Authors noted that phase 3 studies testing the efficacy of combination in earlier lines of therapy for esophagogstric cancer were ongoing [110].

\section{Prostate Cancer}

Efficacy of anti-PD-1 and anti-CTLA-4 antibodies in metastatic prostate cancer patients was tested in a single center prospective phase 2 trial (Table 5). In the study, patients with androgen receptor variant 7 (AR-V7) positive tumors were treated with nivolumab plus ipilimumab combination. At the time of report, ORR in patients with measurable disease was 25\%, median PFS was 3.7 months and OS was 8.2 months. Authors observed that outcomes appeared to be better in tumors with DNA repair deficiency (DRD positive tumors) compared to DRD negative tumors (ORR, $40 \%$ vs $0 \%$ respectively; HR for disease progression, 0.31 and HR for death, 0.41) and concluded that further studies in larger cohort were needed to validate the efficacy of the combination [111].

\section{Sarcoma}

Safety and activity of PD-1 blockade alone or in combination with CTLA-4 blockade was evaluated in an openlabel, non-comparative, randomized phase 2 study in sarcoma patients who received at least one previous line of systemic therapy (Table 5). Patients enrolled in the study received either nivolumab alone or combination of nivolumab and ipilimumab. At the time of assessment, nivolumab and ipilimumab combination group had comparatively higher confirmed responses (16\% versus 5\%), longer median PFS (4.1 months versus 1.7 months) and longer median OS (14.3 months versus 10.7 months). Authors concluded that nivolumab monotherapy showed limited 
efficacy in sarcoma patients and did not warrant further study, whereas nivolumab and ipilimumab combination showed promising efficacy and needed further confirmation through larger randomized study [112].

\section{Summary}

As hypothesized based on their mechanism of action, combination of PD-1 and CTLA-4 blockers has been successful in increasing the response rates and median survival time in cancer patients. Nivolumab plus ipilimumab combination has been approved for 3 indications including, metastatic melanoma, advanced renal cell carcinoma and colorectal cancer with MMR and MSI-H aberrations. Multiple studies demonstrated increased response rates and survival rates in lung cancer patients treated with combination of nivolumab and ipilimumab, and the combination was also seen to be effective in difficult to treat types of cancers such as mesothelioma and sarcoma. However, majority of the studies tested the combination of nivolumab and ipilimumab and only handful of studies evaluated the combination of other PD-1/PD-L1 and CTLA-4 blockers. Further studies may be needed to confirm the efficacy of combining other PD-1 blockers such as pembrolizumab and cemiplimab or PD-L1 blockers such as atezolizumab, avelumab and durvalumab with CTLA-4 blockers such as ipilimumab or tremelimumab. Furthermore, combining nivolumab and ipilimumab was shown to increase the incidence of adverse events and to precipitate auto immunity [113-115]. The severity and incidence of adverse events was shown to be mitigated partly by changing the dose, changing the regimen and changing the sequence of administration of the drugs $[89,91]$. Interestingly, the dose of nivolumab and ipilimumab that showed promising efficacy and limited toxicity appeared to vary with cancer type. For instance, $1 \mathrm{mg} /$ $\mathrm{kg}$ nivolumab plus $3 \mathrm{mg} / \mathrm{kg}$ ipilimumab every 3 weeks was effective dose for treatment of metastatic melanoma and esophagogastric cancer, whereas $3 \mathrm{mg} / \mathrm{kg}$ nivolumab plus $1 \mathrm{mg} / \mathrm{kg}$ ipilimumab every 3 weeks was effective dose for metastatic renal cell carcinoma, metastatic colorectal cancer and sarcoma $[86,100,102,112]$. Similarly, for nonsmall cell lung cancer, nivolumab $3 \mathrm{mg} / \mathrm{kg}$ every 2 weeks plus ipilimumab $1 \mathrm{mg} / \mathrm{kg}$ every 6-12 weeks was shown to be the effective combination. The differences in effective doses of PD- 1 and CTLA- 4 blockers in the combination point to the complex differences in tumor microenvironment in various cancer sub-types. Additional studies are ongoing to titrate the dose, regimen and the administration sequence of the combination (Additional file 1: Table S1 and Additional file 2: Table S2). The results from the studies could provide additional insights into immunosuppressive mechanisms in TME and the significance of CTLA-4 plus PD-1 blockade in respective types of cancer, and help in identifying the combination dose with desired efficacy and adverse event profile.

\section{Conclusions}

In conclusion, combination of CTLA-4 and PD-1 blockers was effective in increasing the response and survival rates in multiple cancer types, but it also increased the incidence of adverse events. Further studies may be needed to reduce the incidence and intensity of the adverse events while preserving the efficacy of the combination. Additional studies are also needed to confirm the efficacy of combination of other CTLA-4 (tremelimumab) and PD-1/PD-L1 (pembrolizumab, cemiplimab, atezolizumab, durvalumab, and avelumab) blockers.

\section{Additional files}

Additional file 1: Table S1. Ongoing clinical trials testing ipilimumab and nivolumab combination. (DOCX $26 \mathrm{~kb}$ )

Additional file 2: Table S2. Ongoing trials testing ipilimumab and pembrolizumab or tremilimumab and durvalumab combination. (DOCX 18 kb)

\begin{abstract}
Abbreviations
APC: Antigen presenting cell; ARv: Androgen receptor variant; CD: Cluster of differentiation; CTLA-4: Cytotoxic T-lymphocyte associated protein 4; dMMR: Mismatch repair deficient; DRD: DNA repair deficiency; HR: Hazard ratio; IL-2: Interleukin-2; MAPK: Mitogen-activated protein kinase; MSIh: Microsatellite instability high; NK cells: Natural killer cells; NKT cells: Natural killer T-cells; NSCLC: Non-small cell lung cancer; ORR: Objective response rate; OS: Overall survival; PD-1: Programmed cell death protein 1; PFS: Progression free survival; PI3K: Phosphoinositide 3-kinase; SCLC: Small cell lung cancer; TME: Tumor microenvironment; Tregs: Regulatory T-cells
\end{abstract}

\section{Acknowledgements}

Author thanks the assistance of Haritha Gotur and Dr Madhuri Bhandaru in the compilation of the data and drafting of the manuscript.

\section{Authors' contributions}

AR conceptualized the review, collected and summarized the data and wrote the manuscript. The author read and approved the final manuscript.

\section{Funding}

No funding received for this study

Availability of data and materials

All data generated or analysed during this study are included in this published article [and its additional files]

Ethics approval and consent to participate

Not applicable

Consent for publication

Not applicable

\section{Competing interests}

The author declares that he/she has no competing interests.

Received: 24 May 2019 Accepted: 31 May 2019

Published online: 13 June 2019

\section{References}

1. Rosenberg SA. IL-2: the first effective immunotherapy for human cancer. J Immunol. 2014;192(12):5451-8.

2. Rotte A, Bhandaru M. Interleukin-2. Immunotherapy of melanoma. Cham: Springer International Publishing; 2016. 
3. Rotte A, Bhandaru M. Interferon-a2b. Immunotherapy of melanoma. Cham: Springer International Publishing; 2016.

4. Rotte A, Bhandaru M, Zhou Y, McElwee KJ. Immunotherapy of melanoma: present options and future promises. Cancer Metastasis Rev. 2015;34(1):115-28.

5. Sanmamed MF, Pastor F, Rodriguez A, Perez-Gracia JL, Rodriguez-Ruiz ME, Jure-Kunkel M, et al. Agonists of Co-stimulation in Cancer Immunotherapy Directed Against CD137, OX40, GITR, CD27, CD28, and ICOS. Semin Oncol. 2015;42(4):640-55.

6. Sanmamed MF, Chen L. A Paradigm Shift in Cancer Immunotherapy: From Enhancement to Normalization. Cell. 2018;175(2):313-26.

7. Darvin P, Toor SM, Sasidharan Nair V, Elkord E. Immune checkpoint inhibitors: recent progress and potential biomarkers. Exp Mol Med. 2018;50(12):165.

8. Looi CK, Chung FF, Leong CO, Wong SF, Rosli R, Mai CW. Therapeutic challenges and current immunomodulatory strategies in targeting the immunosuppressive pancreatic tumor microenvironment. J Exp Clin Cancer Res. 2019;38(1):162.

9. Bhandaru M, Rotte A. Blockade of programmed cell death protein-1 pathway for the treatment of melanoma. Journal of Dermatologic Research and Therapy. 2017;1(2):1-11.

10. Wang X, Guo G, Guan H, Yu Y, Lu J, Yu J. Challenges and potential of PD-1/ PD-L1 checkpoint blockade immunotherapy for glioblastoma. J Exp Clin Cancer Res. 2019;38(1):87.

11. Hargadon KM, Johnson CE, Williams CJ. Immune checkpoint blockade therapy for cancer: An overview of FDA-approved immune checkpoint inhibitors. Int Immunopharmacol. 2018;62:29-39.

12. Rotte A, D'Orazi G, Bhandaru M. Nobel committee honors tumor immunologists. J Exp Clin Cancer Res. 2018:37(1):262.

13. Rotte A, Jin JY, Lemaire V. Mechanistic overview of immune checkpoints to support the rational design of their combinations in cancer immunotherapy. Ann Oncol. 2018;29(1):71-83.

14. Tarhini A. Immune-mediated adverse events associated with ipilimumab ctla-4 blockade therapy: the underlying mechanisms and clinical management. Scientifica (Cairo). 2013;2013:857519.

15. Michot JM, Bigenwald C, Champiat S, Collins M, Carbonnel F, Postel-Vinay S, et al. Immune-related adverse events with immune checkpoint blockade: a comprehensive review. Eur J Cancer. 2016;54:139-48.

16. Brunet JF, Denizot F, Luciani MF, Roux-Dosseto M, Suzan M, Mattei MG, et al. A new member of the immunoglobulin superfamily--CTLA-4. Nature. 1987:328(6127):267-70.

17. Perkins D, Wang Z, Donovan C, He H, Mark D, Guan G, et al. Regulation of CTLA-4 expression during T cell activation. J Immunol. 1996;156(11):4154-9.

18. Alegre ML, Noel PJ, Eisfelder BJ, Chuang E, Clark MR, Reiner SL, et al. Regulation of surface and intracellular expression of CTLA4 on mouse $T$ cells. J Immunol. 1996;157(11):4762-70.

19. Pardoll DM. The blockade of immune checkpoints in cancer immunotherapy Nat Rev Cancer. 2012;12(4):252-64.

20. Fife BT, Bluestone JA. Control of peripheral T-cell tolerance and autoimmunity via the CTLA-4 and PD-1 pathways. Immunol Rev. 2008;224:166-82.

21. Stamper CC, Zhang Y, Tobin JF, Erbe DV, Ikemizu S, Davis SJ, et al. Crystal structure of the B7-1/CTLA-4 complex that inhibits human immune responses. Nature. 2001;410(6828):608-11.

22. Wing $K$, Onishi $Y$, Prieto-Martin $P$, Yamaguchi T, Miyara M, Fehervari $Z$, et al. CTLA-4 control over Foxp3+ regulatory T cell function. Science. 2008; 322(5899):271-5.

23. Krummel MF, Allison JP. CD28 and CTLA-4 have opposing effects on the response of T cells to stimulation. J Exp Med. 1995;182(2):459-65.

24. Leach DR, Krummel MF, Allison JP. Enhancement of antitumor immunity by CTLA-4 blockade. Science. 1996;271(5256):1734-6.

25. Chambers CA, Sullivan TJ, Allison JP. Lymphoproliferation in CTLA-4deficient mice is mediated by costimulation-dependent activation of CD4+ T cells. Immunity. 1997;7(6):885-95.

26. Intlekofer AM, Thompson CB. At the bench: preclinical rationale for CTLA-4 and PD-1 blockade as cancer immunotherapy. J Leukoc Biol. 2013;94(1):25-39.

27. Chikuma S, Abbas AK, Bluestone JA. B7-independent inhibition of T cells by CTLA-4. J Immunol. 2005;175(1):177-81.

28. Schneider $H$, Valk E, Leung R, Rudd CE. CTLA-4 activation of phosphatidylinositol 3-kinase (PI 3-K) and protein kinase B (PKB/AKT) sustains T-cell anergy without cell death. PLoS One. 2008;3(12):e3842.

29. Fraser JH, Rincon M, McCoy KD, Le Gros G. CTLA4 ligation attenuates AP-1, NFAT and NF-kappaB activity in activated T cells. Eur J Immunol. 1999;29(3):838-44.
30. Bhandaru M, Rotte A. Monoclonal Antibodies for the Treatment of Melanoma: Present and Future Strategies. Methods Mol Biol. 2019;1904: 83-108.

31. Rotte A, Bhandaru M. Ipilimumab. Cham, Switzerland: Springer International Publishing; 2016.

32. Ascierto PA, Del Vecchio M, Robert C, Mackiewicz A, Chiarion-Sileni V, Arance $\mathrm{A}$, et al. Ipilimumab $10 \mathrm{mg} / \mathrm{kg}$ versus ipilimumab $3 \mathrm{mg} / \mathrm{kg}$ in patients with unresectable or metastatic melanoma: a randomised, double-blind, multicentre, phase 3 trial. Lancet Oncol. 2017;18(5):611-22.

33. Di Giacomo AM, Ascierto PA, Queirolo P, Pilla L, Ridolfi R, Santinami M, et al. Three-year follow-up of advanced melanoma patients who received ipilimumab plus fotemustine in the Italian Network for Tumor Biotherapy (NIBIT)-M1 phase II study. Ann Oncol. 2015;26(4):798-803.

34. Eggermont AM, Chiarion-Sileni V, Grob JJ, Dummer R, Wolchok JD, Schmidt $\mathrm{H}$, et al. Prolonged Survival in Stage III Melanoma with Ipilimumab Adjuvant Therapy. N Engl J Med. 2016;375(19):1845-55.

35. Eggermont AM, Chiarion-Sileni V, Grob JJ, Dummer R, Wolchok JD, Schmidt $\mathrm{H}$, et al. Adjuvant ipilimumab versus placebo after complete resection of high-risk stage III melanoma (EORTC 18071): a randomised, double-blind, phase 3 trial. Lancet Oncol. 2015;16(5):522-30.

36. Hodi FS, O'Day SJ, McDermott DF, Weber RW, Sosman JA, Haanen JB, et al. Improved survival with ipilimumab in patients with metastatic melanoma. $N$ Engl J Med. 2010;363(8):711-23.

37. Robert C, Thomas L, Bondarenko I, O'Day S, Weber J, Garbe C, et al. Ipilimumab plus dacarbazine for previously untreated metastatic melanoma. N Engl J Med. 2011;364(26):2517-26.

38. Wolchok JD, Neyns B, Linette G, Negrier S, Lutzky J, Thomas L, et al. Ipilimumab monotherapy in patients with pretreated advanced melanoma: a randomised, double-blind, multicentre, phase 2, dose-ranging study. Lancet Oncol. 2010;11(2):155-64.

39. Ishida Y, Agata Y, Shibahara K, Honjo T. Induced expression of PD-1, a novel member of the immunoglobulin gene superfamily, upon programmed cell death. EMBO J. 1992;11(11):3887-95.

40. Rotte A, Bhandaru M. Nivolumab. Switzerland: Springer International Publishing; 2016.

41. Francisco LM, Salinas VH, Brown KE, Vanguri VK, Freeman GJ, Kuchroo VK, et al. PD-L1 regulates the development, maintenance, and function of induced regulatory T cells. J Exp Med. 2009;206(13):3015-29.

42. Latchman Y, Wood CR, Chernova T, Chaudhary D, Borde M, Chernova I, et al. PD-L2 is a second ligand for PD-1 and inhibits T cell activation. Nat Immunol. 2001;2(3):261-8.

43. Keir ME, Butte MJ, Freeman GJ, Sharpe AH. PD-1 and its ligands in tolerance and immunity. Annu Rev Immunol. 2008;26:677-704.

44. Francisco LM, Sage PT, Sharpe AH. The PD-1 pathway in tolerance and autoimmunity. Immunological Reviews. 2010;236(1):219-42.

45. Carreno BM, Bennett F, Chau TA, Ling V, Luxenberg D, Jussif J, et al. CTLA-4 (CD152) can inhibit T cell activation by two different mechanisms depending on its level of cell surface expression. J Immunol. 2000;165(3):1352-6.

46. Sugiura D, Maruhashi T, Okazaki IM, Shimizu K, Maeda TK, Takemoto T, et al. Restriction of PD-1 function by cis-PD-L1/CD80 interactions is required for optimal T cell responses. Science. 2019;364(6440):558-66. https://doi.org/10. 1126/science.aav7062

47. Malek TR, Castro I. Interleukin-2 receptor signaling: at the interface between tolerance and immunity. Immunity. 2010;33(2):153-65.

48. Bennett $F$, Luxenberg $D$, Ling $V$, Wang IM, Marquette $K$, Lowe $D$, et al. Program death-1 engagement upon TCR activation has distinct effects on costimulation and cytokine-driven proliferation: attenuation of ICOS, IL-4, and IL-21, but not CD28, IL-7, and IL-15 responses. J Immunol. 2003;170(2):711-8.

49. Nishimura H, Nose M, Hiai H, Minato N, Honjo T. Development of lupus-like autoimmune diseases by disruption of the PD-1 gene encoding an ITIM motif-carrying immunoreceptor. Immunity. 1999;11(2):141-51.

50. Nishimura H, Okazaki T, Tanaka Y, Nakatani K, Hara M, Matsumori A, et al. Autoimmune dilated cardiomyopathy in PD-1 receptor-deficient mice. Science. 2001;291(5502):319-22.

51. Robert C, Long GV, Brady B, Dutriaux C, Maio M, Mortier L, et al. Nivolumab in previously untreated melanoma without BRAF mutation. N Engl J Med. 2015;372(4):320-30.

52. Weber JS, D'Angelo SP, Minor D, Hodi FS, Gutzmer R, Neyns B, et al. Nivolumab versus chemotherapy in patients with advanced melanoma who progressed after anti-CTLA-4 treatment (CheckMate 037): a randomised, controlled, open-label, phase 3 trial. Lancet Oncol. 2015;16(4):375-84. 
53. Ansell SM, Lesokhin AM, Borrello I, Halwani A, Scott EC, Gutierrez M, et al. PD-1 blockade with nivolumab in relapsed or refractory Hodgkin's lymphoma. N Engl J Med. 2015;372(4):311-9.

54. Borghaei H, Paz-Ares L, Horn L, Spigel DR, Steins M, Ready NE, et al. Nivolumab versus Docetaxel in Advanced Nonsquamous Non-Small-Cell Lung Cancer. N Engl J Med. 2015;373(17):1627-39.

55. Brahmer J, Reckamp KL, Baas P, Crino L, Eberhardt WE, Poddubskaya E, et al. Nivolumab versus Docetaxel in Advanced Squamous-Cell Non-Small-Cell Lung Cancer. N Engl J Med. 2015;373(2):123-35.

56. Carbone DP, Reck M, Paz-Ares L, Creelan B, Horn L, Steins M, et al. First-Line Nivolumab in Stage IV or Recurrent Non-Small-Cell Lung Cancer. N Engl J Med. 2017;376(25):2415-26.

57. Delyon J, Bizot A, Battistella M, Madelaine I, Vercellino L, Lebbe C. PD-1 blockade with nivolumab in endemic Kaposi sarcoma. Ann Oncol. 2018; 29(4):1067-9.

58. Ferris RL, Blumenschein G Jr, Fayette J, Guigay J, Colevas AD, Licitra L, et al. Nivolumab for Recurrent Squamous-Cell Carcinoma of the Head and Neck. N Engl J Med. 2016;375(19):1856-67.

59. George S, Motzer RJ, Hammers HJ, Redman BG, Kuzel TM, Tykodi SS, et al. Safety and Efficacy of Nivolumab in Patients With Metastatic Renal Cell Carcinoma Treated Beyond Progression: A Subgroup Analysis of a Randomized Clinical Trial. JAMA Oncol. 2016;2(9):1179-86.

60. Motzer RJ, Escudier B, McDermott DF, George S, Hammers HJ, Srinivas S, et al. Nivolumab versus Everolimus in Advanced Renal-Cell Carcinoma. N Engl J Med. 2015;373(19):1803-13.

61. Ramchandren R, Domingo-Domenech E, Rueda A, Trneny M, Feldman TA, Lee HJ, et al. Nivolumab for Newly Diagnosed Advanced-Stage Classic Hodgkin Lymphoma: Safety and Efficacy in the Phase II CheckMate 205 Study. J Clin Oncol. 2019:JCO1900315. https://doi.org/10.1200/JCO.19.00315.

62. Bellmunt J, Bajorin DF. Pembrolizumab for Advanced Urothelial Carcinoma. N Engl J Med. 2017;376(23):2304.

63. Bellmunt J, de Wit R, Vaughn DJ, Fradet $Y$, Lee JL, Fong L, et al. Pembrolizumab as Second-Line Therapy for Advanced Urothelial Carcinoma. N Engl J Med. 2017;376(11):1015-26.

64. Chow LQ, Haddad R, Gupta S, Mahipal A, Mehra R, Tahara M, et al. Antitumor Activity of Pembrolizumab in Biomarker-Unselected Patients With Recurrent and/or Metastatic Head and Neck Squamous Cell Carcinoma: Results From the Phase Ib KEYNOTE-012 Expansion Cohort. J Clin Oncol. 2016;34(32):3838-45.

65. Garon EB, Rizvi NA, Hui R, Leighl N, Balmanoukian AS, Eder JP, et al. Pembrolizumab for the treatment of non-small-cell lung cancer. N Engl J Med. 2015;372(21):2018-28.

66. Giaccone G, Kim C, Thompson J, McGuire C, Kallakury B, Chahine JJ, et al. Pembrolizumab in patients with thymic carcinoma: a single-arm, singlecentre, phase 2 study. Lancet Oncol. 2018;19(3):347-55.

67. Reck M, Rodriguez-Abreu D, Robinson AG, Hui R, Csoszi T, Fulop A, et al. Pembrolizumab versus Chemotherapy for PD-L1-Positive Non-Small-Cell Lung Cancer. N Engl J Med. 2016;375(19):1823-33.

68. Ribas A, Puzanov I, Dummer R, Schadendorf D, Hamid O, Robert C, et al. Pembrolizumab versus investigator-choice chemotherapy for ipilimumabrefractory melanoma (KEYNOTE-002): a randomised, controlled, phase 2 trial. Lancet Oncol. 2015;16(8):908-18.

69. Robert C, Schachter J, Long GV, Arance A, Grob JJ, Mortier L, et al. Pembrolizumab versus Ipilimumab in Advanced Melanoma. N Engl J Med. 2015:372(26):2521-32

70. Fuchs CS, Doi T, Jang RW, Muro K, Satoh T, Machado M, et al. Safety and Efficacy of Pembrolizumab Monotherapy in Patients With Previously Treated Advanced Gastric and Gastroesophageal Junction Cancer: Phase 2 Clinical KEYNOTE-059 Trial. JAMA Oncol. 2018;4(5):e180013.

71. Shitara K, Ozguroglu M, Bang YJ, Di Bartolomeo M, Mandala M, Ryu MH, et al. Pembrolizumab versus paclitaxel for previously treated, advanced gastric or gastro-oesophageal junction cancer (KEYNOTE-061): a randomised, openlabel, controlled, phase 3 trial. Lancet. 2018;392(10142):123-33.

72. Kang YK, Boku N, Satoh T, Ryu MH, Chao Y, Kato K, et al. Nivolumab in patients with advanced gastric or gastro-oesophageal junction cancer refractory to, or intolerant of, at least two previous chemotherapy regimens (ONO-4538-12, ATTRACTION-2): a randomised, double-blind, placebo-controlled, phase 3 trial. Lancet. 2017:390(10111):2461-71.

73. Rosenberg JE, Hoffman-Censits J, Powles T, van der Heijden MS, Balar AV, Necchi A, et al. Atezolizumab in patients with locally advanced and metastatic urothelial carcinoma who have progressed following treatment with platinumbased chemotherapy: a single-arm, multicentre, phase 2 trial. Lancet. 2016; 387(10031):1909-20.
74. Rittmeyer A, Barlesi F, Waterkamp D, Park K, Ciardiello F, von Pawel J, et al. Atezolizumab versus docetaxel in patients with previously treated nonsmall-cell lung cancer (OAK): a phase 3, open-label, multicentre randomised controlled trial. Lancet. 2017;389(10066):255-65.

75. Fehrenbacher L, Spira A, Ballinger M, Kowanetz M, Vansteenkiste J, Mazieres $J$, et al. Atezolizumab versus docetaxel for patients with previously treated non-small-cell lung cancer (POPLAR): a multicentre, open-label, phase 2 randomised controlled trial. Lancet. 2016;387(10030):1837-46.

76. Peters S, Gettinger S, Johnson ML, Janne PA, Garassino MC, Christoph D, et al. Phase II Trial of Atezolizumab As First-Line or Subsequent Therapy for Patients With Programmed Death-Ligand 1-Selected Advanced Non-SmallCell Lung Cancer (BIRCH). J Clin Oncol. 2017;35(24):2781-9 JCO2016719476.

77. Kaufman HL, Russell J, Hamid O, Bhatia S, Terheyden P, D'Angelo SP, et al. Avelumab in patients with chemotherapy-refractory metastatic Merkel cell carcinoma: a multicentre, single-group, open-label, phase 2 trial. Lancet Oncol. 2016;17(10):1374-85.

78. Antonia SJ, Villegas A, Daniel D, Vicente D, Murakami S, Hui R, et al. Durvalumab after Chemoradiotherapy in Stage III Non-Small-Cell Lung Cancer. N Engl J Med. 2017;377(20):1919-29.

79. Powles T, O'Donnell PH, Massard C, Arkenau HT, Friedlander TW, Hoimes CJ, et al. Efficacy and Safety of Durvalumab in Locally Advanced or Metastatic Urothelial Carcinoma: Updated Results From a Phase 1/2 Open-label Study. JAMA Oncol. 2017;3(9):e172411.

80. Migden MR, Rischin D, Schmults CD, Guminski A, Hauschild A, Lewis KD, et al. PD-1 Blockade with Cemiplimab in Advanced Cutaneous Squamous-Cell Carcinoma. N Engl J Med. 2018;379(4):341-51.

81. Maher VE, Fernandes LL, Weinstock C, Tang S, Agarwal S, Brave M, et al. Analysis of the Association Between Adverse Events and Outcome in Patients Receiving a Programmed Death Protein 1 or Programmed Death Ligand 1 Antibody. J Clin Oncol. 2019:JCO1900318. https://doi.org/10.1200/ JCO.19.00318.

82. Tivol EA, Borriello F, Schweitzer AN, Lynch WP, Bluestone JA, Sharpe AH. Loss of CTLA-4 leads to massive lymphoproliferation and fatal multiorgan tissue destruction, revealing a critical negative regulatory role of CTLA-4. Immunity. 1995;3(5):541-7.

83. Nishimura H, Honjo T. PD-1: an inhibitory immunoreceptor involved in peripheral tolerance. Trends Immunol. 2001;22(5):265-8.

84. Wolchok JD, Kluger H, Callahan MK, Postow MA, Rizvi NA, Lesokhin AM, et al. Nivolumab plus ipilimumab in advanced melanoma. N Engl J Med. 2013; 369(2):122-33.

85. Postow MA, Chesney J, Pavlick AC, Robert C, Grossmann K, McDermott D, et al. Nivolumab and ipilimumab versus ipilimumab in untreated melanoma. N Engl J Med. 2015;372(21):2006-17.

86. Larkin J, Chiarion-Sileni V, Gonzalez R, Grob JJ, Cowey CL, Lao CD, et al. Combined Nivolumab and Ipilimumab or Monotherapy in Untreated Melanoma. N Engl J Med. 2015;373(1):23-34.

87. Wolchok JD, Chiarion-Sileni V, Gonzalez R, Rutkowski P, Grob JJ, Cowey CL, et al. Overall Survival with Combined Nivolumab and Ipilimumab in Advanced Melanoma. N Engl J Med. 2017;377(14):1345-56.

88. Hodi FS, Chiarion-Sileni V, Gonzalez R, Grob JJ, Rutkowski P, Cowey CL, et al. Nivolumab plus ipilimumab or nivolumab alone versus ipilimumab alone in advanced melanoma (CheckMate 067): 4-year outcomes of a multicentre, randomised, phase 3 trial. Lancet Oncol. 2018:19(11):1480-92.

89. Long GV, Atkinson V, Cebon JS, Jameson MB, Fitzharris BM, MCNeil CM, et al. Standard-dose pembrolizumab in combination with reduced-dose ipilimumab for patients with advanced melanoma (KEYNOTE-029): an openlabel, phase 1b trial. Lancet Oncol. 2017;18(9):1202-10.

90. Tawbi HA, Forsyth PA, Algazi A, Hamid O, Hodi FS, Moschos SJ, et al. Combined Nivolumab and Ipilimumab in Melanoma Metastatic to the Brain. N Engl J Med. 2018;379(8):722-30.

91. Weber JS, Gibney G, Sullivan RJ, Sosman JA, Slingluff CL Jr, Lawrence DP, et al. Sequential administration of nivolumab and ipilimumab with a planned switch in patients with advanced melanoma (CheckMate 064): an openlabel, randomised, phase 2 trial. Lancet Oncol. 2016;17(7):943-55.

92. Hodi FS, Chesney J, Pavlick AC, Robert C, Grossmann KF, McDermott DF, et al. Combined nivolumab and ipilimumab versus ipilimumab alone in patients with advanced melanoma: 2-year overall survival outcomes in a multicentre, randomised, controlled, phase 2 trial. Lancet Oncol. 2016;17(11): 1558-68.

93. Meerveld-Eggink A, Rozeman EA, Lalezari F, van Thienen JV, Haanen J, Blank CU. Short-term CTLA-4 blockade directly followed by PD-1 blockade in 
advanced melanoma patients: a single-center experience. Ann Oncol. 2017; 28(4):862-7.

94. Kirchberger MC, Hauschild A, Schuler G, Heinzerling L. Combined low-dose ipilimumab and pembrolizumab after sequential ipilimumab and pembrolizumab failure in advanced melanoma. Eur J Cancer. 2016;65:182-4.

95. D'Angelo SP, Larkin J, Sosman JA, Lebbe C, Brady B, Neyns B, et al. Efficacy and Safety of Nivolumab Alone or in Combination With Ipilimumab in Patients With Mucosal Melanoma: A Pooled Analysis. J Clin Oncol. 2017; 35(2):226-35.

96. Kirchberger MC, Moreira A, Erdmann M, Schuler G, Heinzerling L. Real world experience in low-dose ipilimumab in combination with PD-1 blockade in advanced melanoma patients. Oncotarget. 2018;9(48):28903-9.

97. Blank CU, Rozeman EA, Fanchi LF, Sikorska K, van de Wiel B, Kvistborg P, et al. Neoadjuvant versus adjuvant ipilimumab plus nivolumab in macroscopic stage III melanoma. Nat Med. 2018;24(11):1655-61.

98. Hammers HJ, Plimack ER, Infante JR, Rini BI, McDermott DF, Lewis LD, et al. Safety and Efficacy of Nivolumab in Combination With Ipilimumab in Metastatic Renal Cell Carcinoma: The CheckMate 016 Study. J Clin Oncol. 2017;35(34):3851-8 JCO2016721985

99. Motzer RJ, Tannir NM, McDermott DF, Aren Frontera O, Melichar B, Choueiri TK, et al. Nivolumab plus Ipilimumab versus Sunitinib in Advanced RenalCell Carcinoma. N Engl J Med. 2018;378(14):1277-90.

100. Cella D, Grunwald V, Escudier B, Hammers HJ, George S, Nathan P, et al. Patient-reported outcomes of patients with advanced renal cell carcinoma treated with nivolumab plus ipilimumab versus sunitinib (CheckMate 214): a randomised, phase 3 trial. Lancet Oncol. 2019;20(2):297-310.

101. Overman MJ, McDermott R, Leach JL, Lonardi S, Lenz HJ, Morse MA, et al. Nivolumab in patients with metastatic DNA mismatch repair-deficient or microsatellite instability-high colorectal cancer (CheckMate 142): an openlabel, multicentre, phase 2 study. Lancet Oncol. 2017;18(9):1182-91.

102. Overman MJ, Lonardi S, Wong KYM, Lenz HJ, Gelsomino F, Aglietta M, et al. Durable Clinical Benefit With Nivolumab Plus Ipilimumab in DNA Mismatch Repair-Deficient/Microsatellite Instability-High Metastatic Colorectal Cancer. J Clin Oncol. 2018;36(8):773-9 JCO2017769901.

103. Antonia S, Goldberg SB, Balmanoukian A, Chaft JE, Sanborn RE, Gupta A, et al. Safety and antitumour activity of durvalumab plus tremelimumab in non-small cell lung cancer: a multicentre, phase $1 \mathrm{~b}$ study. Lancet Oncol. 2016;17(3):299-308.

104. Hellmann MD, Rizvi NA, Goldman JW, Gettinger SN, Borghaei H, Brahmer JR, et al. Nivolumab plus ipilimumab as first-line treatment for advanced nonsmall-cell lung cancer (CheckMate 012): results of an open-label, phase 1, multicohort study. Lancet Oncol. 2017;18(1):31-41.

105. Hellmann MD, Ciuleanu TE, Pluzanski A, Lee JS, Otterson GA, AudigierValette C, et al. Nivolumab plus Ipilimumab in Lung Cancer with a High Tumor Mutational Burden. N Engl J Med. 2018;378(22):2093-104.

106. Ready N, Hellmann MD, Awad MM, Otterson GA, Gutierrez M, Gainor JF, et al. First-Line Nivolumab Plus Ipilimumab in Advanced Non-Small-Cell Lung Cancer (CheckMate 568): Outcomes by Programmed Death Ligand 1 and Tumor Mutational Burden as Biomarkers. J Clin Oncol. 2019;37(12):992-1000.

107. Antonia SJ, Lopez-Martin JA, Bendell J, Ott PA, Taylor M, Eder JP, et al. Nivolumab alone and nivolumab plus ipilimumab in recurrent small-cell lung cancer (CheckMate 032): a multicentre, open-label, phase 1/2 trial. Lancet Oncol. 2016;17(7):883-95.

108. Disselhorst MJ, Quispel-Janssen J, Lalezari F, Monkhorst K, de Vries JF, van der Noort $V$, et al. Ipilimumab and nivolumab in the treatment of recurrent malignant pleural mesothelioma (INITIATE): results of a prospective, singlearm, phase 2 trial. Lancet Respir Med. 2019;7(3):260-70.

109. Scherpereel A, Mazieres J, Greillier L, Lantuejoul S, Do P, Bylicki O, et al. Nivolumab or nivolumab plus ipilimumab in patients with relapsed malignant pleural mesothelioma (IFCT-1501 MAPS2): a multicentre, open-label, randomised, non-comparative, phase 2 trial. Lancet Oncol. 2019;20(2):239-53

110. Janjigian YY, Bendell J, Calvo E, Kim JW, Ascierto PA, Sharma P, et al. CheckMate-032 Study: Efficacy and Safety of Nivolumab and Nivolumab Plus Ipilimumab in Patients With Metastatic Esophagogastric Cancer. J Clin Oncol. 2018;36(28):2836-44.

111. Boudadi K, Suzman DL, Anagnostou V, Fu W, Luber B, Wang H, et al. Ipilimumab plus nivolumab and DNA-repair defects in AR-V7-expressing metastatic prostate cancer. Oncotarget. 2018;9(47):28561-71.

112. D'Angelo SP, Mahoney MR, Van Tine BA, Atkins J, Milhem MM, Jahagirdar $\mathrm{BN}$, et al. Nivolumab with or without ipilimumab treatment for metastatic sarcoma (Alliance A091401): two open-label, non-comparative, randomised, phase 2 trials. Lancet Oncol. 2018;19(3):416-26.

113. Johnson DB, Balko JM, Compton ML, Chalkias S, Gorham J, Xu Y, et al. Fulminant Myocarditis with Combination Immune Checkpoint Blockade. N Engl J Med. 2016;375(18):1749-55.

114. Mehta A, Gupta A, Hannallah F, Koshy T, Reimold S. Myocarditis as an immune-related adverse event with ipilimumab/nivolumab combination therapy for metastatic melanoma. Melanoma Res. 2016;26(3):319-20.

115. Cappelli LC, Gutierrez AK, Baer AN, Albayda J, Manno RL, Haque U, et al. Inflammatory arthritis and sicca syndrome induced by nivolumab and ipilimumab. Ann Rheum Dis. 2017;76(1):43-50.

\section{Publisher's Note}

Springer Nature remains neutral with regard to jurisdictional claims in published maps and institutional affiliations.
Ready to submit your research? Choose BMC and benefit from:

- fast, convenient online submission

- thorough peer review by experienced researchers in your field

- rapid publication on acceptance

- support for research data, including large and complex data types

- gold Open Access which fosters wider collaboration and increased citations

- maximum visibility for your research: over $100 \mathrm{M}$ website views per year

At $\mathrm{BMC}$, research is always in progress.

Learn more biomedcentral.com/submissions 